\title{
Facts on Organizational Performance in Indonesia
}

\author{
B Medina Nilasari* \\ Magister Manajemen \\ Universitas Trisakti \\ Jakarta Indonesia \\ *medina@trisakti.ac.id
}

\begin{abstract}
The purpose of this research is to examine social media on employee performance with entrepreneurial orientation as a mediating variable. Structural Equation Model (SEM) method used in this study. Respondent in this research were management-level employees, namely general managers, managers, head departments, and officers from Inna Group Hotel which is consist of 14 hotels in Indonesia. The total sample of this research is 220 people. The result showed that all variables are significant. Hotel leaders need to focus on social media to look for hotel industry trends, competitor information, and customer information. The entrepreneurial orientation of hotel managers needs to be improved so that managers are entrepreneurial. An entrepreneur will take decisions that are proactive, innovative, and risk-taking.
\end{abstract}

Keywords—social media usage, entrepreneurial orientation, organizational performance

\section{INTRODUCTION}

Social media has changed the business environment. Currently companies are leveraging technology using platforms using social media for business matters, including customers, stakeholders, customer service, developing content, and engaging consumers in product development [1]. The benefits of social media for companies are to reducing lower costs and better efficiency [2].

Social media affects organizational performance in Malaysia including cost reduction, improve customer relations, and increase information accessibility. Social media also positively influences entrepreneurial orientation [3]. In general, performance is always associated with finance. Good organizational performance is usually only seen from the results of financial statements that show positive profits. But the performance results are considered inappropriate if only seen from one financial course [4].

In the electronics industry, the most important point is entrepreneurial orientation [5]. New businesses with entrepreneurial orientation such as innovation, behaviour, proactive, and impact on superior performance [6]. Several studies showed how the impact of entrepreneurial orientation on company performance [7].

\section{LITERATURE REVIEW}

Social media is influenced by interactivity, costeffectiveness, and compatibility were very important factors for the use of social media, there is a positive relationship [8].

H1: Social media usage has a positive effect on organizational performance.

Entrepreneurial orientation is influenced by social media [3]. Companies with high entrepreneurial orientation perform better and make greater use of the internet [9].

$\mathrm{H} 2$ : Social media usage has a positive effect on entrepreneurial orientation.

The effect of entrepreneurial orientation on firm performance is more positive in new businesses that make cognitive, regulatory, and normative efforts than those who do not carry out this legitimacy $[6,7]$.

H3: Entrepreneurial orientation has a positive effect on organizational performance.

Based on the theoretical basis and previous studies that have formed the first, second, and third hypotheses, the fourth hypothesis can be arranged as follows:

H4: Entrepreneurial Orientation mediates the effect of social media usage on organizational performance.

\section{METHODS}

The research design used was a hypothesis testing. The population of this study is the management level employees of Inna Group Hotel consisting of General Managers, Managers, Head Departments, and Officers. Data collection was assisted by the Hotel Indonesia Natour Human Resources Department, which distributed online questionnaire links to HR units consisting of 14 units (14 hotels in Java, Bali, and Sumatra with 220 respondents using an online questionnaire. SEM methods used to analytical data.

All indicators have a value $>0.4$ indicating valid results and all dimensions have a value of $>0.7$ indicating reliable results [10]. 
TABLE I. RESULT OF VALIDITY AND RELIABILITY TEST

\begin{tabular}{|c|c|c|c|c|}
\hline Variable & Dimension & Indicator & Factor Loading & Cronbach's Alpha \\
\hline \multirow{10}{*}{$\begin{array}{l}\text { Organizational } \\
\text { Performance }\end{array}$} & \multirow{4}{*}{ Cost Reduction } & OPCR1 & 0.924 & 0.958 \\
\hline & & OPCR2 & 0.959 & \\
\hline & & OPCR3 & 0.962 & \\
\hline & & OPCR4 & 0.929 & \\
\hline & \multirow[t]{3}{*}{ Improved Customer Relations \& Service } & SOPCRS1 & 0.898 & \multirow{3}{*}{0.900} \\
\hline & & OPCRS2 & 0.932 & \\
\hline & & OPCRS3 & 0.914 & \\
\hline & \multirow[t]{3}{*}{ Enhanced Information Accessibility } & OPIA1 & 0.934 & \multirow{3}{*}{0.921} \\
\hline & & OPIA2 & 0.953 & \\
\hline & & OPIA3 & 0,903 & \\
\hline \multirow{11}{*}{$\begin{array}{l}\text { Social Media } \\
\text { Usage }\end{array}$} & \multirow[t]{4}{*}{ SMU for Marketing } & SMM1 & 0.921 & \multirow[t]{4}{*}{0.925} \\
\hline & & SMM2 & 0.913 & \\
\hline & & SMM3 & 0.869 & \\
\hline & & SMM4 & 0.921 & \\
\hline & \multirow[t]{4}{*}{ SMU for Customer service \& relations } & SMCRS1 & 0.887 & \multirow{4}{*}{0.923} \\
\hline & & SMCRS2 & 0.910 & \\
\hline & & SMCRS3 & 0.929 & \\
\hline & & SMCRS4 & 0.888 & \\
\hline & \multirow[t]{3}{*}{ SMU for Information Accessibility } & SMIA1 & 0.928 & \multirow{3}{*}{0.917} \\
\hline & & SMIA2 & 0.926 & \\
\hline & & SMIA3 & 0.924 & \\
\hline \multirow{9}{*}{$\begin{array}{l}\text { Entrepreneuria } \\
\text { Orientation }\end{array}$} & \multirow[t]{3}{*}{ Proactiveness } & EOP1 & 0.862 & \multirow[t]{3}{*}{0.741} \\
\hline & & EOP2 & 0.850 & \\
\hline & & EOP3 & 0.760 & \\
\hline & \multirow[t]{3}{*}{ Risk-Taking } & EORT1 & 0.806 & \multirow{3}{*}{0.800} \\
\hline & & EORT2 & 0.889 & \\
\hline & & EORT3 & 0.846 & \\
\hline & \multirow[t]{3}{*}{ Innovativeness } & EOI1 & 0.927 & \multirow[t]{3}{*}{0.902} \\
\hline & & EOI2 & 0.948 & \\
\hline & & EOI3 & 0.880 & \\
\hline
\end{tabular}

Source: Data Processing 2019

TABLE II. GOODNESS OF FIT

\begin{tabular}{|c|c|c|c|c|}
\hline Types of Goodness of Fit & Goodness of Fit Measure & Level of Acceptance & Calculating Measure & Acceptable \\
\hline \multirow[t]{3}{*}{\begin{tabular}{|l|} 
Absolute \\
Fit Measure
\end{tabular}} & $\begin{array}{l}\text { Chi-square } \\
\text { p-value }\end{array}$ & $\begin{array}{l}\text { Small chi-square } \\
\text { p-value } \geq 0.05\end{array}$ & $\begin{array}{l}436.854(\mathrm{df}=143) \\
0.000\end{array}$ & Poor \\
\hline & RMSEA & 0.10 & 0.097 & \multirow{5}{*}{ Good fit } \\
\hline & RMR & & 0.000 & \\
\hline Fit Measure & \begin{tabular}{|l|} 
TNIT \\
TLI
\end{tabular} & \multirow{5}{*}{$>0.90$ or close to 1} & 0.925 & \\
\hline & CFI & & 0.938 & \\
\hline & IFI & & 0.938 & \\
\hline Parsimonious & \begin{tabular}{|l} 
AGFI \\
\end{tabular} & & 0.770 & \multirow{2}{*}{ Acceptable Fit } \\
\hline Fit Measure & PNFI & & 0.761 & \\
\hline
\end{tabular}

Testing mediation variables obtained using the SOBEL test [11]:

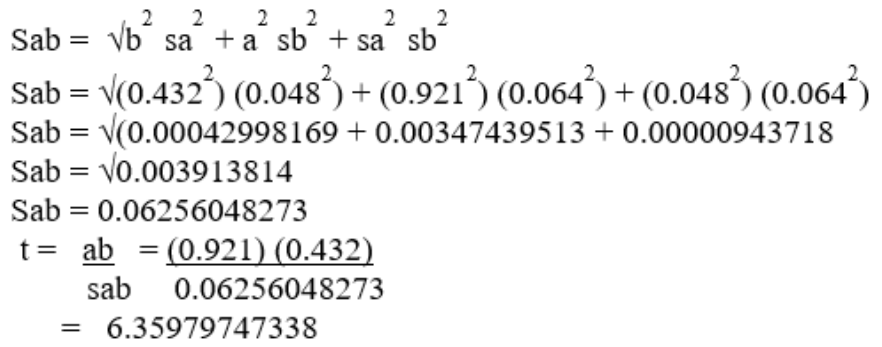

Information:

Source: Data Processing 2019

- $\mathrm{b}$ : The value of the standardized estimate lane $\mathrm{b}$

- a: The value of the standardized estimate lane a

- sa: Standard Error (SE) lane a

- $\quad$ sb: Standard Error (SE) path b

Based on the results it is showed that entrepreneurial orientation as a mediated variable with t-value $6.36>\mathrm{t}$-table 1.96. 


\section{RESULTS AND DISCUSSION}

\section{A. Results}

TABLE III. HYPOTHESIS TEST RESULTS

\begin{tabular}{|l|l|l|l|}
\hline \multicolumn{1}{|c|}{ Hypothesis } & Coefficient & C.R & p-value \\
\hline $\begin{array}{l}\text { H1: Social media usage has a } \\
\text { positive effect on organizational } \\
\text { performance. }\end{array}$ & 0.585 & 7.497 & $0.000^{*}$ \\
\hline $\begin{array}{l}\text { H2: Social media usage has a } \\
\text { positive effect on entrepreneurial } \\
\text { orientation. }\end{array}$ & 0.921 & 20.553 & $0.000^{*}$ \\
\hline $\begin{array}{l}\text { H3: Entrepreneurial orientation } \\
\text { has a positive effect on } \\
\text { organizational performance. }\end{array}$ & 0.432 & 5.783 & $0.000 *$ \\
\hline $\begin{array}{l}\text { H4: Entrepreneurial Orientation } \\
\text { mediates the effect of social } \\
\text { media usage on organizational } \\
\text { performance. }\end{array}$ & 0.398 & 6.361 & $0.000 *$ \\
\hline
\end{tabular}

\section{B. Discussion}

The first hypothesis showed that social media usage has a positive impact on organizational performance. For this reason, social media usage must be maintained [12]. Social media usage is used by hotels to: advertise products, promote products, marketing research, get references, customer feedback, customer advice about product/newly launched services, reach new customers, look for trends in the hotel industry, find information about competitors, and find information about customers [3,8].

The second hypothesis showed that the use of social media has a positive effect on entrepreneurial orientation. For this reason, social media usage must be maintained in order to improve entrepreneurial orientation [3,9].

The third hypothesis showed that entrepreneurial orientation significantly influences organizational performance. Entrepreneurial orientation at the hotel such as the hotel actively responds to the actions of competitors, ambitions to be the foremost among competitors, uses more resources than competitors in exploiting business opportunities, implements some risky programs to achieve sales growth, implements programs even at high costs, accepting uncertainty in every program that runs, trying new ideas, looking for new ways to implement the program, the first to do marketing for a new product/service $[6,7]$.

The fourth hypothesis showed that the effect of social media usage on organizational performance through entrepreneurial orientation is positive and significant. This shows that the more proactive, innovative and risk-taking respondents, the more influence the use of social media for marketing, customer relations and service, and the use of social media for access to information, on the performance.

\section{CONCLUSION}

All the results of this study support the proposed hypothesis, this is an indicator that the function of the tested variable has been achieved properly and is supported by the object of research. The weaknesses of this research are the number of respondents and methods. Further research is suggested to increase the number of respondents to more than a thousand and adopt a longitudinal approach method [3].

\section{REFERENCES}

[1] W. Pride, R.J. Hudges and J.R. Kapoor, Foundation of Business (Fifth edition). Cengage Learning, 2017.

[2] A.L. Harris and A. Rea, "Web 2.0 and virtual world technologies," Journal of IS Education, vol. 20, no. 2, pp. 137-144, 2009.

[3] F. Parveen, N.I. Jaafar and S. Ainin, "Social media's impact on organizational performance and entrepreneurial orientation in organizations," Management Decision, vol. 54, no. 9, pp. 2208-2234, 2016.

[4] Y. Anshori, Manajemen Strategi Hotel (Strategi Meningkatkan Inovasi dan Kinerja). ITS Press, 2010.

[5] D.A. Colton, M.S. Roth and W.O. Bearden, "Drivers of international etail performance the complexities of orientation and resources," Journal of International Marketing, vol. 18, no. 1, pp. 1-22, 2010.

[6] T. Wang, S. Thornhill and J.O. De Castro, "Entrepreneurial orientation, legitimation, and new venture performance," Strategic Entrepreneurship Journal, vol. 11, no. 4, pp. 373-392, 2017.

[7] J. Wiklund and D. Shepherd, "Knowlwdge based resources, entrepreneurial orientation, and the Performance of small and medium sized business," Strategic Management Journal, vol. 24, pp. 1307-1314, 2003.

[8] R. Odoom, T. Anning-Darson and G. Acheampong, "Antecendents of social media usage and performance benefits in small- and mediumsized ent.erprise (SMEs)," Journal of Enterprise Information Managament, vol. 30, no. 3, pp. 383-399, 2017.

[9] R.H. Mostafa, C. Wheeler and M. Jones, "Entrepreneurial orientation, commitment to the internet and export performance in small and medium sized exporting firms," Journal of International Entrepreneurship, vol. 3, no. 4, pp. 291-302, 2006.

[10] J.F. Hair, R.E. Anderson and W.C. Black, Multivariate Data Analysis, Upper Saddle River. New Jersey: Prentice Hall Inc., 2014.

[11] I. Ghozali, Model Persamaan Struktural, Konsep dan Aplikasi dengan Program AMOS 24. Semarang: BP-UNDIP, 2017.

[12] J.J. Shuai and W.W. Wu, "Evaluating the influences of e-marketing on hotel performance by DEA and Grey Entrophy," Expert Systems with Applications, vol. 38, no. 7, pp. 8763-8769, 2011. 